\title{
Editorial
}

\section{The Clinician through the Looking Glass: Sputum Microbiology in COPD Exacerbations}

\author{
Demosthenes Bouros $^{a} \quad$ Ioannis Pneumatikos ${ }^{b}$ \\ a Department of Pneumonology and ${ }^{b}$ Intensive Care Unit, Medical School, Democritus University of Thrace, \\ and University Hospital of Alexandroupolis, Alexandroupolis, Greece
}

Acute exacerbations in COPD (AECOPD) typically include increased breathlessness, sputum volume and sputum purulence perhaps accompanied by increased cough, wheeze and chest tightness. Although most AECOPD are self-limited they are associated with substantial decreases in the quality of life and account for a large fraction of expenditures for the treatment of COPD, since they are the most common cause of hospitalization among patients with this disease [1].

The most common causes of an AECOPD are infections of the tracheobronchial tree and air pollution; however, the cause in about one third of severe exacerbations cannot be identified [2]. For many years there has been controversy about whether bacteria play a role in AECO$\mathrm{PD}$ and thus whether antibiotics have a role in disease management. Most evidence about the role of infection has been derived from bacteriologic cultures of respiratory secretions, which have been studied either qualitatively or quantitatively [3]. About half of the AECOPD yield positive sputum cultures and the isolation rate may be increased by the selection of purulent samples. The most common isolated species are Haemophilus influenzae, Streptococcus pneumoniae, and Moraxella catarrhalis. Nevertheless, this information has not always been useful in addressing the role of infection, since patients with COPD typically have chronic airway colonization and the presence of bacteria in airway secretions (even in high concentrations) does not establish an etiologic role in exacerbations.

Recent studies using molecular techniques suggest that different strains of the same pathogen are capable of evading host defense, infecting the airways and causing new episodes of AECOPD $[4,5]$. The host antibody response to different strains of some pathogens is essential in the understanding and prevention of AECOPD [6]. In the near future these observations probably will justify a more reasonable use of antibiotics in AECOPD.

In this issue of Respiration, Roche et al. [7] prospectively assessed the yield of the microbiological examination of purulent sputum in 118 patients with COPD hospitalized in a medical ward for at least one episode of acute exacerbation. Culture was performed for all sputum samples irrespective of quality criteria ( $>25$ polymorphonuclear leukocytes and $<10$ epithelial cells per low power field at $100 \times$ magnification). An arbitrarily high cutoff point $\left(>10^{7} \mathrm{CFU} / \mathrm{ml}\right)$ was chosen in order to minimize the inclusion of contaminants. A positive bacterial culture was obtained from $59 \%$ of purulent sputum samples. Although no protected bronchial sampling was performed, the results suggest that leukocyte count was a more important quality criterion than the number of epithelial cells. Moreover, restricting the culture to samples that fulfil both criteria leads to discarding a high number of samples which would be positive. As it has

\section{KARGER}

Fax +4161306 1234 E-Mail karger@karger.ch www.karger.com
(C) 2007 S. Karger AG, Basel

0025-7931/07/0741-0013\$23.50/0

Accessible online at:

www.karger.com/res
Demosthenes Bouros, MD, FCCP

Professor of Pneumonology, Head, Department of Pneumonology

Medical School, University of Thrace, University Hospital of Alexandroupolis

GR-68100 Alexandroupolis, Thrace (Greece)

Tel./Fax +30 25510 76106, E-Mail bouros@med.duth.gr 
been shown that this could be a useful clinical criterion in daily clinical practice, the aspect of the sputum may be a reliable criterion for bacterial load by itself $[8,9]$.

Another important finding is that all sputum samples with positive culture contained a predominant microbial population at direct examination. In contrast, of all sputum samples where no predominant microbial population could be identified, none were positive in culture. This observation underlines the importance of Gram staining that is often omitted or underestimated in clinical practice. Since the usefulness of sputum examination is low in community-acquired pneumonia the extrapolation of this practice to AECOPD does not seem justified. Sputum microbiological examination with Gram stain- ing and leukocyte count should be performed routinely in patients hospitalized for AECOPD with purulent sputum especially in those with severe disease $\left(\mathrm{FEV}_{1}<50 \%\right.$ predicted), long-term oxygen therapy and bronchiectasis.

However, some caveats are important. First, only hospitalized patients were included in this study. Second, only exacerbations with purulent sputum were included. Third, no protected bronchial sampling was performed. Further prospective studies taking these limitations into account are warranted. Also, the pathogenic role of bacterial infection in exacerbations of COPD should be further investigated, especially the role of bacterial infection in relation to local and systemic inflammation $[10,11]$.

\section{References}

1 Viegi G, Scognamiglio A, Baldacci S, Pistelli F, Carrozzi L: Epidemiology of chronic obstructive pulmonary disease (COPD). Respiration 2001;68:4-19.

2 White AJ, Compertz S, Stockley RA: Chronic obstructive pulmonary disease. 6 . The aetiology of exacerbations of chronic obstructive pulmonary disease. Thorax 2003;58: 73-80.

3 Monso E, Ruiz J, Rossel A, Manterola J, Fiz J, Ausina V: Bacterial infection in chronic obstructive pulmonary disease: a study of stable and exacerbated outpatients using protected specimen brush. Am J Respir Crit Care Med 1995;152:1316-1320.
4 Sethi S, Evans N, Grant BJB, Murphy TE: New strains of bacteria and exacerbations of chronic obstructive pulmonary disease. N Engl J Med 2002;347:465-471.

5 Murphy TF, Brauer AL, Grant BJB, Sethi S: Moraxella catarrhalis in chronic obstructive pulmonary disease: burden of disease and immune response. Am J Respir Crit Care Med 2005;172:195-199.

6 Sethi S, Wrona C, Grant BJB, Murphy TE: Strain specific immune response to Haemophilus influenzae in chronic obstructive pulmonary disease. Am J Respir Crit Care Med 2004;169:448-453.

7 Roche N, Kouassi B, Rabbat A, Mounedji A, Lorut C, Huchon G: Yield of sputum microbiological examination in patients hospitalized for exacerbations of chronic obstructive pulmonary disease with purulent sputum. Respiration 2007;74:19-25.
8 Antthonisen NR, Manfreda J, Warren CP, et al: Antibiotic therapy in exacerbations of chronic obstructive pulmonary disease. Ann Intern Med 1987;106:196-204.

9 Stockley RA, O’Brien C, Pye A, Hill SL: Relationship of sputum color to nature and outpatients management of acute exacerbations of COPD. Chest 200;117:1638-1645.

10 Pistelli F, Viegi G: How to predict exacerbations and hospital admissions in stable COPD outpatients? Respiration 2000;67: 491-492.

11 Groenewegen KH, Wouters EF: Bacterial infections in patients requiring admission for an acute exacerbation of COPD; a 1-year prospective study. Respir Med 2003;97:770777. 